\title{
Globorotaliid intervals of the sub-evaporite Badenian (Middle Miocene) in the Upper Silesia Basin (Central Paratethys, Poland)
}

\author{
Małgorzata GONERA ${ }^{1, *}$ \\ 1 Polish Academy of Sciences, Institute of Nature Conservation, Al. A. Mickiewicza 33, 31-120 Kraków, Poland
}

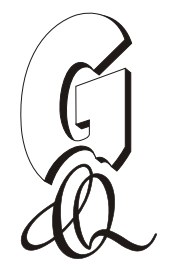

Gonera M (2013) Globorotaliid intervals of the sub-evaporite Badenian (Middle Miocene) in the Upper Silesia Basin (Central Paratethys, Poland). Geological Quarterly, 57 (4): 757-768, doi: 10.7306/gq.1125

\begin{abstract}
Globorotaliids of the Skawina Formation (Badenian) come from deposits representing CPN 7 (Orbulina suturalis Zone) and CPN 8 sub-evaporite Wielician (Globigerina druryi-G. decoraperta Zone alias Uvigerina costai Zone) age. There are two taxonomic groups of globorotaliids in the studied material: globoconellids (Globoconella bykovae and G. minoritesta) and jenkinsellids (Jenkinsella mayeri and J. transsylvanica). There are five stratigraphically-rank intervals of these foraminifers prior to the Middle Badenian salinity crisis in Central Paratethys. The investigated Badenian begins with $G$. bykovae-J. mayeri association followed by the first occurence (FO) of J. transsylvanica. The closing member of the CPN 7 biozone is the G. bykovae-J. transsylvanica assemblage. The jenkinsellids disappear during CPN 7: J. mayeri first and $J$. transsylvanica after. Since the base of CPN 8 in situ jenkinsellids have not been noted in the Badenian deposits. The CPN 8 begins with a stratigraphic interval barren of globorotaliids (biozone IIC in the Polish Paratethys). It is followed by episodic appearances of globoconellids (G. bykovae and G. minoritesta) in the sub-evaporite Wielician (IID biozone in Poland). G. minoritesta has been found in only one case so far. The globorotaliid stratigraphic units are distinct and well-correlated with changes in climate and the circulation of water masses in Paratethys. This study provides additional data on Mi3 in Paratethys. It documents a cryptic cooling event in the late Orbulina suturalis Zone (mid CPN 7) located at the late IIA-B assemblage (alias upper lagenide zone) in regional biostratigraphic scale. The event is recorded by J. transsylvanica Acme, matching with circa $1 \% \mathrm{VPDB} \delta^{18} \mathrm{O}$ positive excursion. The event must have resulted in a considerable sea level drop - a trigger of the Moravian ecosystem demolition in the Paratethys environment.
\end{abstract}

Key words: Middle Miocene, Badenian, foraminifers, Globorotaliidae, Paratethys.

\section{INTRODUCTION}

Globorotaliids (Family Globorotaliidae Cushman, 1927) are trochospiral non-spinose planktonic foraminifera which appeared in the Paleocene (Loeblich and Tappan, 1988). Recent globorotaliids are deep-dwellers of the epipelagic zone (Bé, 1977; Hemleben et al., 1989) and show a wide latitudinal range: from subarctic to subantarctic regions. Living at a depth $100-200 \mathrm{~m}$ below sea surface the group is not as highly tuned to climate as the shallow-dwelling Globigerinina (e.g., Globigerinoides), nevertheless globorotallids display different relative abundances of particular species in respect of latitude.

Cenozoic globorotaliids evolved rapidly during the Cenozoic and their major radiation occurred in the Miocene (e.g., Kennett and Srinivasan, 1983). The family gave rise to many stratigraphic datums as the first and/or last appearance of selected members. Globorotaliids species are also used in global and regional biostratigraphic schemes for zone definitions (e.g., laccarino, 1985; Berggren et al., 1995).

\footnotetext{
*E-mail: gonera@iop.krakow.pl
}

Received: June 7, 2013; accepted: October 13, 2013; first published online: October 23, 2013
The circum-Carpathian area was one of the marine Miocene basins located NE of the Neogene Mediterranean province. The area had been defined by Laskarev (1924) as Paratethys and categorized by Seneš (1959) as Central Paratethys (Fig. 1A). The Miocene marine deposits of this area are both coastal and basinal in origin (the summarising data in Steininger et al., 1985; Oszczypko et al., 2006); the latter of which contains a variety and abundance of planktonic foraminifera.

The globorotaliids appeared in the Paratethys during the Early Miocene Egerian (Cicha et al., 1998). The group was most fertile during the Orbulina suturalis Zone of Badenian - the interval of the largest marine expansion in the region (Fig. 2). The Carpathian Foredeep and the eastern part of the Intra-Carpathian Basin (comprising the Transcarpathian, Transylvanian and East Slovakian Neogene basins) were deep sea environments at that time. Environmental niches suitable to globorotaliids developed well in these parts of the Paratethys. Impoverished globorotaliids are present occasionally yet in the Late Badenian deposits and definitely are missing in the Sarmatian (Cicha et al., 1975, 1998).

Although the Badenian globorotaliids were described from numerous sites, sections and areas of the Paratethys, up to now the group has not been analysed as a biostratigraphic marker (neither as particular taxa nor as globorotaliid associations). The aim of this paper is to evaluate the biostratigraphic potential of the group. 


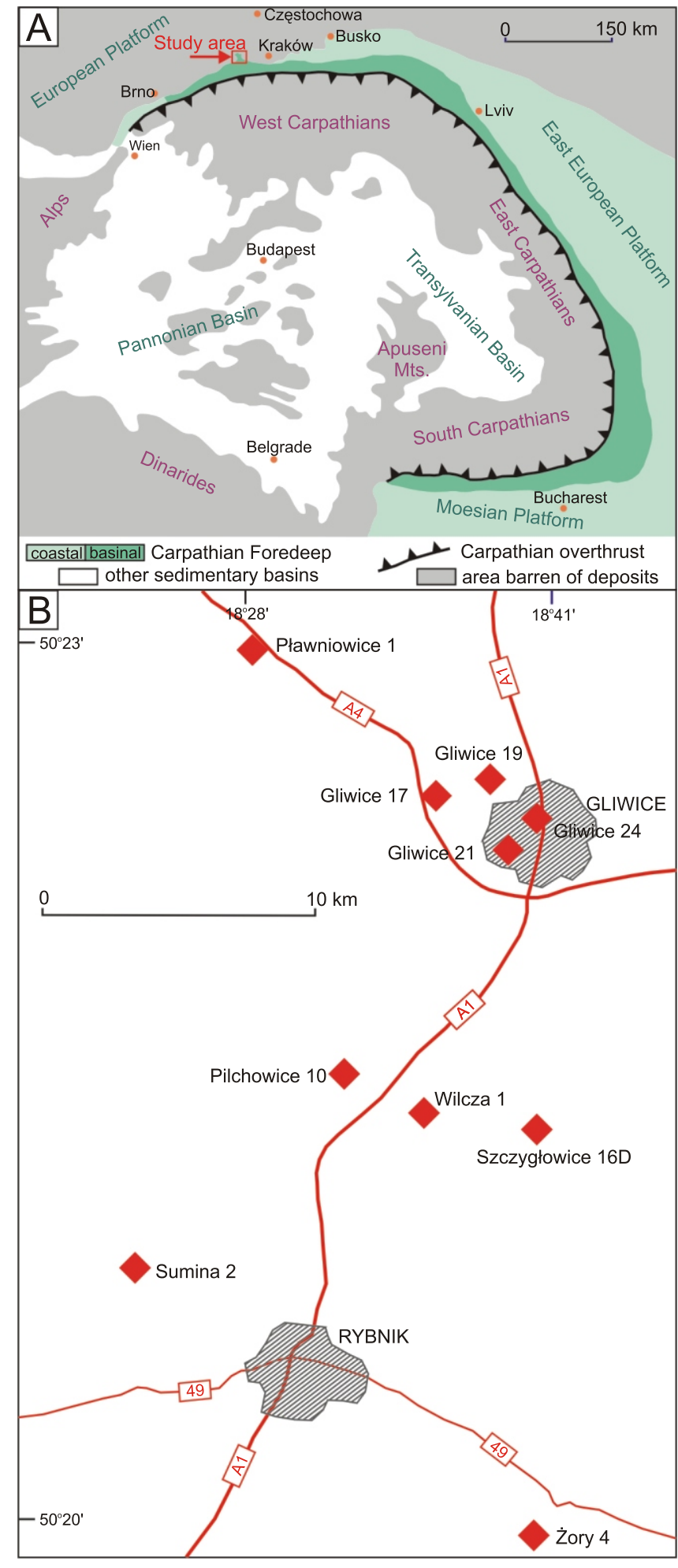

Fig. 1. Location map

A - distribution of Middle Miocene marine deposits in Central Paratethys (modified after Seneš, 1971 and Rögl, 1998); B - location of the studied boreholes

\section{GEOLOGICAL SETTING}

The Upper Silesia Basin is located in a part of Paratethys between the Moravian type area to the west (vicinity of Brno) and the type areas of both the Wielician (near Kraków) and the Kosovian (Ukrainian Carpathian Foredeep, south of Lviv) situated to the east.

Carboniferous and Triassic units are the basement of the Miocene deposition of the Upper Silesia Basin. The thickness of the Miocene cover ranges here from about 60 to about 600 metres. The sedimentation began in the Karpatian when brackish and freshwater deposits of the Kłodnica Formation (Alexandrowicz, 1997) formed. These deposits occur in patches and reach up to $70 \mathrm{~m}$ in thickness. The Badenian starts with the marine sediments of the Skawina Formation (the Moravian and the sub-evaporite Wielician) attaining $161.5 \mathrm{~m}$ in thickness (mean value $66.0 \mathrm{~m}$ ). Evaporites of Wielician age (Wieliczka and Krzyżanowice formations) occur in a large part of the Silesia Basin (Garlicki, 1979). They are 14.5-57.2 m thick (mean value $30.9 \mathrm{~m}$ ). In situ foraminifers are absent in the evaporites. Marine deposits of normal salinity of the Kosovian substage are developed in the supra-evaporite Badenian (Gliwice Formation). This unit attains $343.3 \mathrm{~m}$ in thickness (mean value $120.3 \mathrm{~m}$ ) but locally is lacking. Upwards in the Gliwice Fm. foraminifers successively become impoverished both in terms of number of taxa and quantity of specimens. Finally foraminifers disappear in the overlying Kędzierzyn Formation. The Skawina Fm. and Gliwice Fm. are characterized by considerable temporal changes in the taxonomic set of foraminifera (Alexandrowicz, 1963). Particular assemblages were defined as assemblage biozones ( 5 and 6 in Fig. 2). Palaeoecological methods applied to characterize these assemblages revealed that this foraminiferal stratigraphic succession formed in a response to considerable palaeoenvironmental changes (Gonera, 2001). These changes were so significant that taxonomic differences of the consecutive biozones are conspicuous. Due to the environmental changes, ongoing populations of foraminifera were subject to elimination by ecological selection. These constraints led to taxonomic substitutions and occurrence of a new assemblage (biozone) adapted to the new circumstances.

Climate and climate-driven circulation patterns of the palaeocurrents have been pointed to as the crucial environmental factors controlling the Badenian biozones (Gonera, 2001). The biozones used in this paper are the ecozones formed as foraminiferal response to the first-order factors. Two principal circulation patterns in the studied Paratethys Basin have been recognised: anti-estuarine followed by estuarine (Fig. 2). In the Miocene Upper Silesia Basin the Mi3 record has been initially recognized by foraminifera (Gonera, 2001; Bicchi et al., 2003) and foraminiferal $\delta^{18} \mathrm{O}$ levels (Gonera et al., 2003) and has been recently confirmed by radiometric data (Leeuw et al., 2010).

Through foraminiferal palaeoecology it has been interpreted that the Wielician evaporite sedimentation ceased because of the climate amelioration, resulted in both air humidity and eustatic sea level increases (Gonera, 2001). The new pattern of circulation established as the result of activation of both continental runoff of freshwater and seawater influx due to eustatic level rise. The interaction between these two water masses were balanced by estuarine circulation patterns at the studied area. Unlike the sub-evaporite Badenian, the youngest marine sediments display rich siliceous plankton: radiolarians (Barwicz-Piskorz, 1997) and diatoms (Witkowski and Gonera, 1997). 


\begin{tabular}{|c|c|c|c|c|c|c|c|c|}
\hline \multirow{2}{*}{\multicolumn{2}{|c|}{ Chronostratigraphy }} & \multicolumn{5}{|c|}{$\begin{array}{l}\text { Biozonation after: } 1 \text { - Cicha et al. (1975); } 2 \text { - Papp et al. (1978a); } \\
\text { 3- Rögl and Steininger (1984); } 4 \text { - Steininger et al. (1985); } \\
\text { 5 - Alexandrowicz }(1963,1997) ; 6 \text { - Łuczkowska (1964) }\end{array}$} & \multicolumn{2}{|c|}{$\begin{array}{c}\text { Major palaeoenvironmetal events } \\
\text { (after Gonera, 2001) }\end{array}$} \\
\hline & & & $1-6$ & & 5 & 6 & Circulation & Climate \\
\hline \multirow{8}{*}{ 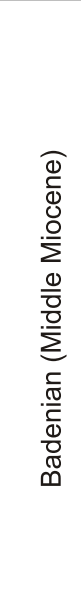 } & 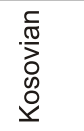 & $\begin{array}{l}a \\
2 \\
0 \\
0\end{array}$ & $\begin{array}{l}\text { Velapertina } \\
\text { Zone }\end{array}$ & $\begin{array}{l}\text { Bulimina-Bolivina } \\
\text { zone }\end{array}$ & IIIB & $\begin{array}{c}\text { Hanzawaia } \\
\text { crassiseptata }\end{array}$ & $\begin{array}{l}\text { E4 (vigorous } \\
\text { estuarine) }\end{array}$ & \\
\hline & \multirow{4}{*}{ 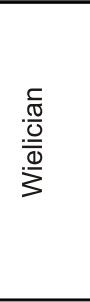 } & \multirow{4}{*}{$\begin{array}{l}\infty \\
z \\
0\end{array}$} & \multirow{4}{*}{$\begin{array}{l}\text { Globigerina } \\
\text { druryi-G } \\
\text { decoraperta } \\
\text { Zone }\end{array}$} & \multirow{4}{*}{$\begin{array}{l}\text { zone with } \\
\text { agglutinated } \\
\text { foraminifera }\end{array}$} & IIIA & Neobulimina longa & $\begin{array}{c}\text { E3 (sluggish } \\
\text { estuarine) } \\
\end{array}$ & \\
\hline & & & & & \multicolumn{4}{|c|}{ Evaporite deposits } \\
\hline & & & & & IID & \multirow{2}{*}{ Uvigerina costai } & \multirow{3}{*}{$\begin{array}{l}\text { E2 (sluggish } \\
\text { anti-estuarine) }\end{array}$} & \\
\hline & & & & & IIC & & & $\mathrm{Mi} 3$ \\
\hline & \multirow{3}{*}{$\begin{array}{l}\sum_{\frac{\pi}{\pi}}^{\frac{\pi}{\pi}} \\
\frac{0}{2} \\
\sum\end{array}$} & \multirow{3}{*}{$\begin{array}{l}\hat{z} \\
\text { o } \\
0\end{array}$} & \multirow{3}{*}{$\begin{array}{c}\text { Orbulina } \\
\text { suturalis Zone }\end{array}$} & \multirow{3}{*}{ Lagenidae zone } & $\| \beta$ & \multirow{3}{*}{ Orbulina suturalis } & & \\
\hline & & & & & IIB & & \multirow{2}{*}{$\begin{array}{c}\text { E1 (vigorous } \\
\text { anti-estuarine) }\end{array}$} & \\
\hline & & & & & IIA & & & \\
\hline
\end{tabular}

Fig. 2. Central Paratethys stratigraphic units and location of the Skawina Formation studied samples (shadowed)

\section{MATERIAL AND METHODS}

Material for this study comes from fourteen boreholes analysed already with regard to planktonic and benthic foraminiferal palaeoecology (Gonera, 2001). These boreholes crossed the Skawina Fm. deposits from the beginning of the Badenian transgression up to the Wielician salinity crisis. Orbulina suturalis Zone (CPN 7) and Globigerina druryi-G. decoraperta Zone (CPN 8) sediments occur in each borehole except for the Gliwice 17 borehole where the CPN 8 deposits are lacking. The boreholes are located along $\mathrm{N}-\mathrm{S}$ transect of the Upper Silesia Basin (Fig. 1B). The thickness of the studied Skawina Fm. deposits ranges from $27.3 \mathrm{~m}$ (Szczygłowice 16D) to $161.5 \mathrm{~m}$ (Pilchowice 10). Globorotaliids have been re-analysed in lithologically different deposits (Appendix 1). Most of them are marly clays but there is also a number of sandy marls and several samples of marly clays comprising rhodolith debris.

Globorotaliids are numerous in all CPN 7 samples (138 in total) whereas only four of the $33 \mathrm{CPN} 8$ samples contain globorotaliids tests in amounts exceeding $1 \%$ of planktonic foraminifera. Due to statistic procedure requirements (i.e. reliability level of the counting) only the samples with globorotaliid abundancy exceeding $1 \%$ of planktonic foraminifera have been selected for quantitative analysis. Altogether 118 such samples have been examined (Appendix 1).

The analyses of globorotaliids have been performed in the fraction $125-430 \mu \mathrm{m}$. Due to the statistical treatment of data as many as 324 (on the average) globorotaliid tests per sample have been taxonomically identified and quantified. The volume of the residuum in analysed samples had been from 0.5 to $1.0 \mathrm{~cm}^{3}$.

\section{RESULTS}

TAXONOMY

Two globorotaliids subsets (genera) have been recognized in the studied sediments: Globoconella and Jenkinsella (system- atics after Kennett and Srinivasan, 1983). Both Globoconella and Jenkinsella are represented by two morphospecies (Figs. 3 and 4): G. bykovae (Subbotina et al., 1960) and G. minoritesta (Papp et al., 1978b), and J. mayeri (sensu Bolli and Saunders, 1982) and J. transsylvanica (Popescu, 1970), respectively.

\section{STRATIGRAPHIC DISTRIBUTION}

Percentages of Globoconella, Jenkinsella, Globoquadrina altispira (Cushman and Jervis, 1936), Globigerina bulloides d'Orbigny, 1826, Globigerinella obesa (Bolli, 1957), Globigerinoides quadrilobatus (d'Orbigny, 1846), Turborotalita quinqueloba (Natland, 1938) and Orbulina suturalis Bronnimann, 1951 had been counted. Frequency data of those taxa are considered here in the time-consecutive parts of Badenian and in regard to their ecological preferences (e.g., Bé, 1977). A simple classification of warmer vs. cooler taxa and their dwelling preferences have been applied as a basic data to ecological consideration. As taxonomic diversity is higher in warmer areas and lower in cooler ones (Bé, 1977) these datasets are auxiliary applied to justify interpretation on climate. Additionally, the index of planktonic foraminiferal diversity in the particular examined biozones (a number of the mentioned taxa) has been applied to appreciate the pelagic habitat. The recognized distinct assemblages of globorotaliids and their stratigraphic position are labelled tentatively by simple semi-acronyms (Table 1; Fig. 5).

IIA-B. The thickness of these sediments ranges from $14.5 \mathrm{~m}$ (Pławniowice 1) to $100.8 \mathrm{~m}$ (Gliwice 19). They have been analysed in 97 samples. Planktonic foraminifer frequency varied from $15 \%$ to $92 \%$ (mean value $61 \%$ ) of total foraminifera. Pelagic foraminifer biocenoses have 3-8 taxa (median $=6)$. There is Globigerinoides quadrilobatus (mean value $18 \%$ ) in the shallow epipelagic. In the deeper epipelagic Globoconella bykovae prevails (mean value $28 \%$ ). Jenkinsella sp. div. (mean value $22 \%$ ) and Globigerina bulloides (mean value $21 \%$ ) are also very common. The biozone IIA-B is bipartite in regard of the globorotaliids set (Table 1).

Lower in the section there is Globoconella bykovae-Jenkinsella mayeri assemblage (interval $b-m$ ). The plank- 

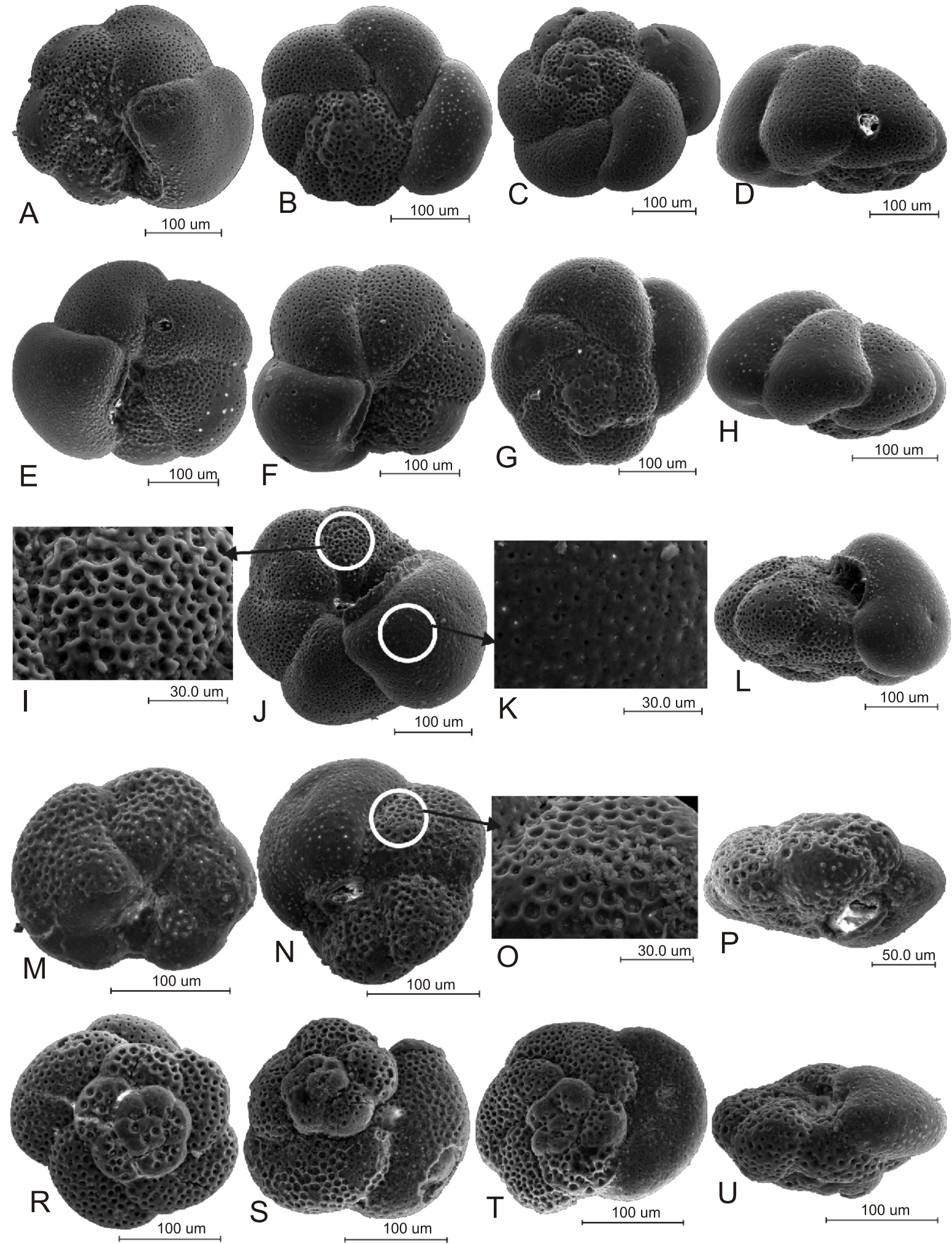

Fig. 3. SEM pictures of the Skawina Formation globorotaliids

A-L - Globoconella bykovae: Sumina 2, $325.0 \mathrm{~m}$ (A - umbilical view, B - dorsal view); Gliwice 17, $183.0 \mathrm{~m}$ (C - dorsal view, D - edge view); Gliwice 17, 230.0 m (E - umbilical view); Pławniowice 1, 130.0 m (F - umbilical view); Gliwice 24, $163.0 \mathrm{~m}$ (G - dorsal view, H - edge view); Żory 4, $55.0 \mathrm{~m}$ (I - ultrastructure, J - umbilical view, K - ultrastructure); Gliwice 21, $190.0 \mathrm{~m}$ (L - edge view); M-U - Globoconella minoritesta: Gliwice 19, 172.0 m (M, N - umbilical view, O - ultrastructure, P - edge view, R-T - dorsal view, U - edge view) 

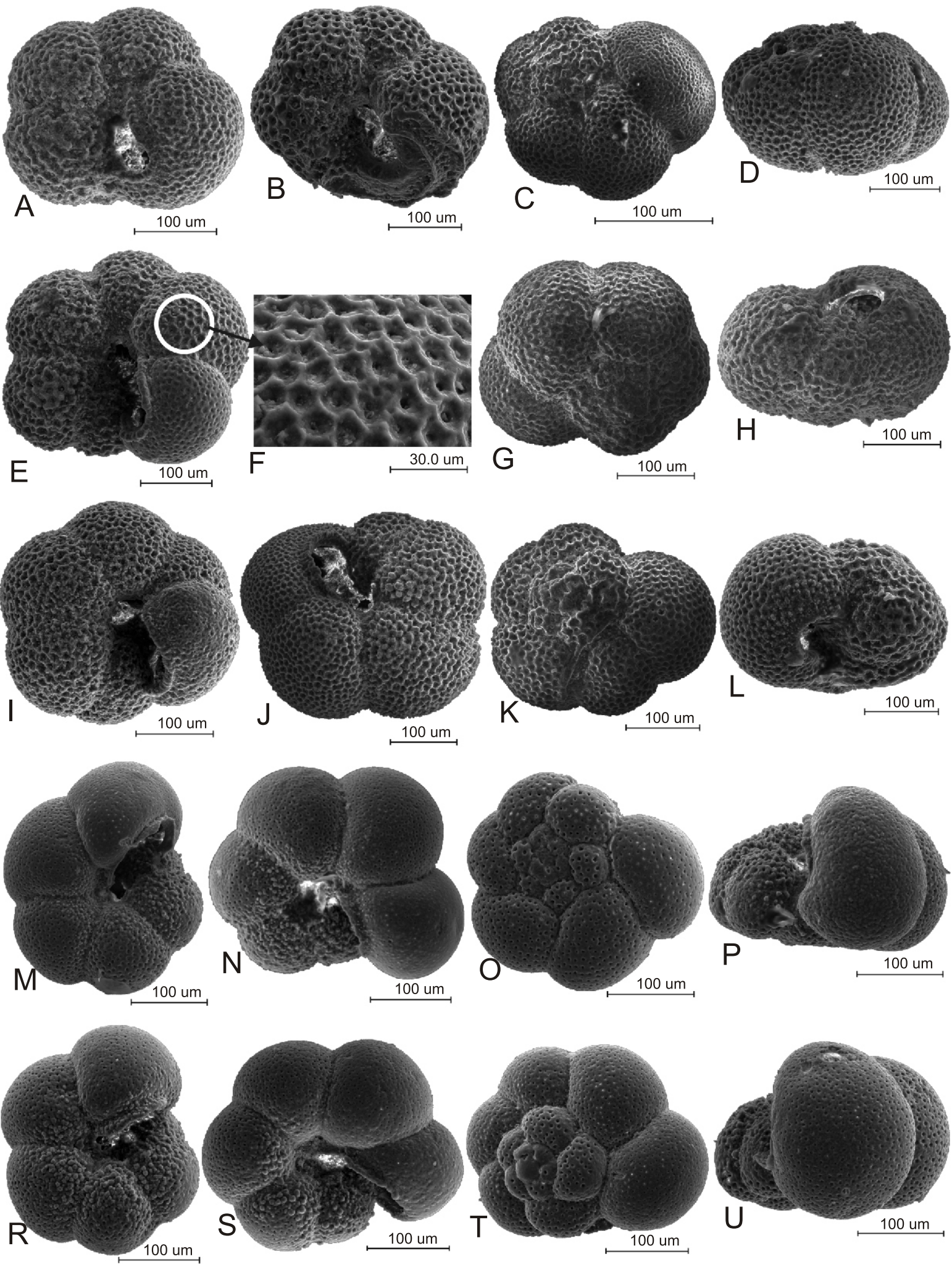

Fig. 4. SEM pictures of the Skawina Formation globorotaliids

A-L - Jenkinsella mayeri: Wilcza 1, $132.0 \mathrm{~m}$ ( A - umbilical view, B - umbilical view); Gliwice 17, $222.3 \mathrm{~m}$ (C - dorsal view, D - edge view); Gliwice 19, 245.0 m (E - umbilical view, F - ultrastructure); Gliwice 21, $243.0 \mathrm{~m}$ (G - dorsal view, H - edge view, I - umbilical view); Pilchowice $10 \mathrm{~m}, 595.0 \mathrm{~m}$ (J - umbilical view); Gliwice 24, $200.0 \mathrm{~m}$ (K - dorsal view, L - edge view); M-U - Jenkinsella transsylvanica: Gliwice 24, 186.4 m (M - umbilical view, N - umbilical view); Gliwice 17, 202.5 m (O - dorsal view, P - edge view); Pławniowice 1, $139.0 \mathrm{~m}$ ( $\mathrm{R}$ - umbilical view, S - umbilical view); Żory 4, $130.0 \mathrm{~m}$ (T - dorsal view, U - edge view) 


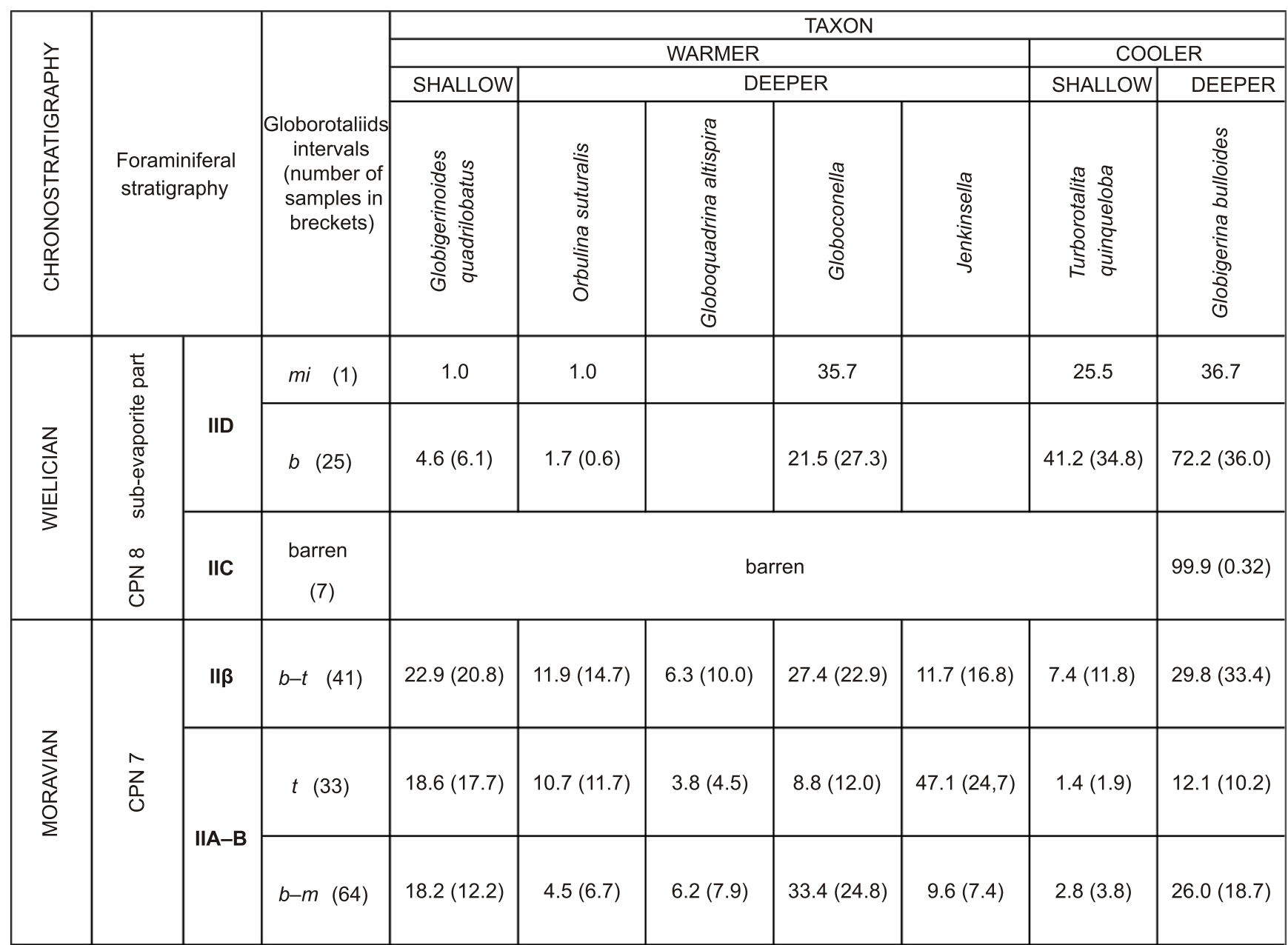

globorotaliid levels: $b-m-$ Globoconella bykovae-Jenkinsella mayeri, $t$ - Jenkinsella transsylvanica, $b-t-G$. bykovae-J. transsylvanica, $b-$ G. bykovae, mi - G. minoritesta

tonic foraminiferal frequency in this unit is 15-83\% (median $56 \%$ ). In shallow pelagic waters G. quadrilobatus (median = $15 \%)$ occurs. Deeper epipelagic waters are dominated by $G$. bykovae $($ median $=30 \%$ ) and G. bulloides ( median $=23 \%$ ), with the third most abundant taxon being Jenkinsella mayeri (median $=8 \%$ ). In this lower globorotaliids horizons the number of planktonic foraminifera taxa varies from 4 to 8 (median $=7$ ).

Higher in the section Jenkinsella transsylvanica is present (interval $t$ ). The planktonic foraminifera frequent vary here from 40-92\% (median $=68 \%)$. A median of shallow-dwelling species (G. quadrilobatus) is $13 \%$. In deeper pelagic waters $\mathrm{J}$. transsylvanica dominates (median $=44 \%$ ), though there are minor amounts of Globigerina bulloides (median $=8 \%$ ), Globigerinella obesa $($ median $=7 \%$ ) and Orbulina suturalis $(\mathrm{me}-$ dian $=5 \%$ ). The number of planktonic taxa in this upper globorotaliids horizons varies from 3 to 8 (median $=6$ ).

At the border of these remarkable two globorotallids levels a major change in deeper-dwellers is recorded: Jenkinsella mayeri disappears and Jenkinsella transsylvanica appears. The first appearance of Jenkinsella transsylvanica tests is regarded as the beginning of this taxon interval. The taxon very quickly becomes the only globorotaliid in the section (Appendix 1). The taxon constitutes almost half of all planktonic specimens in its acme stratigraphic zone (Table 1). It is accompanied by some specimens of Globigerinoides quadrilobatus, Globigerina bulloides and Orbulina suturalis which double their percentage in comparison to the lower part of IIA-B biozone. In the upper globorotallid level there is a significant increase of planktonic foraminifera percentage compared to the earlier globorotaliid level.

II $\beta$. The biozone has been not recorded in Gliwice 17 and Wilcza 1 boreholes. Its thickness in the remaining boreholes ranges from $5.5 \mathrm{~m}$ (Gliwice 24) to $30.0 \mathrm{~m}$. (Żory 4). Planktonic foraminifera frequency in this closing biozone of the CPN 7 is 19-96\% (median $=55 \%$ ), and thus is lower than that noted in IIA-B biozone. The number of taxa is from 3 to 8 here (median $=6$ ). The diversified set of planktonic foraminifer taxons, analogous to IIA-B biozone, is in II $\beta$ incidentally substituted by monotypic biocenosis of Globigerina bulloides. Such intercalations, where G. bulloides constitutes $90 \%$ of planktonic tests, had been traced in Gliwice $19(177.0 \mathrm{~m}, 179.0 \mathrm{~m})$, Gliwice 21 (181.0 m), Gliwice 24 (158.0 m, $159.0 \mathrm{~m}, 161.0 \mathrm{~m})$ and Sumina 2 (305.0 m); because of a negligible number of globorotaliid tests these samples are not included in Appendix 1. Compared to the 


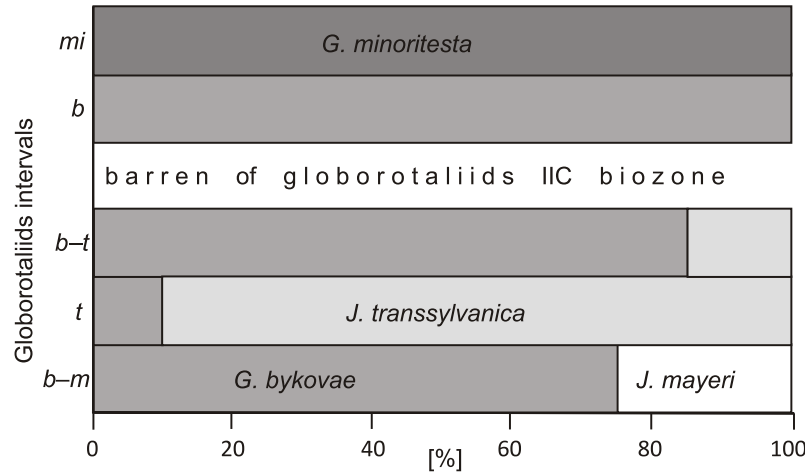

Fig. 5. General scheme of the stratigraphic distribution of the globorotaliids levels in the sub-evaporite Badenian sediments of the Silesian Basin (Central Paratethys)

Explanations as in Table 1

preceding biozone (IIA-B) there is a significant increase of the Turborotalita quinqueloba specimens. This taxon with $G$. quadrilobatus (median $=16$ ) as the shallow-dwellers of this biozone constitute one fifth of the whole planktonic foraminifera. In deeper pelagic waters there is a high number of $G$. bykovae $($ median $=24 \%)$ and Globigerina bulloides $($ median $=14)$. Small quantities of $O$. suturalis (median $=7$ ), Jenkinsella transsylvanica (median $=5$ ) and Globoquadrina altispira (median $=2 \%$ ) are also present here. G. bykovae dominants in the globorotaliid assemblage, accompanied by small amounts of $G$. transsylvanica in just half of the analysed samples.

IIC. The sediments of this biozone appear only in four amongst the fourteen studied boreholes (Gonera, 2001). Three of them are examined in the present paper (Pilchowice 10, Wilcza 1, Żory 4). The thickness of the biozone varies from $6.9 \mathrm{~m}$ (Wilcza 1) to $34.0 \mathrm{~m}$ (Pilchowice 10). The planktonic foraminifera percentage is $78-100 \%$ (median $=88 \%$ ). In all the studied samples there are solely Globigerina bulloides tests (median = $100 \%$ ). This initial biozone of the Wielician (Uvigerina costai Zone or CPN 8) is barren of globorotaliids.

IID. The sediments of this biozone are present in all boreholes, apart from Gliwice 17. The thickness ranges from $5.4 \mathrm{~m}$ (Gliwice 21) do $30.1 \mathrm{~m}$ (Żory 4). Planktonic foraminiferal frequency widely differs in this biozone. It ranges from 1 to $100 \%$ ( median $=20 \%$ ). Globigerina bulloides dominates in this biozone (median $=91 \%)$ though Turborotalita quinqueloba also commonly occurs (median $=38 \%$ ). The presence of globorotaliids if they are present at all - is highly episodic in IID. The more numerous specimens $($ median $=17 \%$ ) are noted in four of the boreholes and they are represented solely by globoconellids. In three of the boreholes (Pławniowice 1, Sumina 2 and Żory 4) they are Globoconella bykovae (median 9\%) and in one borehole (Gliwice 19) Globoconella minoritesta (36\% of planktonic foraminifera). The stratigraphic order of these two appearances cannot be concluded and it is tentatively put that $G$. minoritesta is the later representative (Table 1; Fig. 5). Besides the aforementioned taxons, single specimens of Globigerinella obesa $($ median $=4 \%)$, Globigerinoides quadrilobatus $($ median $=3 \%)$ and Orbulina suturalis (median $=2 \%$ ) are present in some of the IID biozone samples. It is also noteworthy that there are no Jenkinsella or Globoquadrina altispira specimens present.

\section{INTERPRETATION}

The Middle Miocene succession of globorotaliids in the Upper Silesia Basin documents the state and attitude of these deep epipelagic foraminifers to environmental changes (Gonera, 2001). During IIA-B biozone the water-exchange between the Paratethys and relatively open marine realm had a vigorous anti-estuarine circulation pattern (E1 in Fig. 2). This type of flow had been established due to the latitudinal gradient of atmospheric temperature between the Paratethys and Tethys waters. Based on foraminifers the temperature of the surface waters was ca. $20^{\circ} \mathrm{C}$ (Szczechura, 1982; Gonera, 2001). Warmer and lighter surface waters inflowing from lower latitudes had undergone cooling northward (Upper Silesia Basin). The descending cooler waters flowed out as a bottom current. As can be inferred based on foraminiferal data (Gonera, 2001) the basin depth ranged from outer shelf (north margin) to upper bathyal (south margin). The sea level stand was high enough to assure the effective water-exchange between Paratethys and its alimentary (Tethys) basin(s). Warm epipelagic water and the significant depth of the Upper Silesia Basin caused a strong temperature-controlled stratification of water column. Vertical mixing of the basin waters was negligible, if it occurred at all, during this phase. Some water exchange in this direction ran mainly in costal areas especially in the cooler north part of the Paratethys (Gonera, 2001).

A characteristic pattern of life resources and their stability in the environment had been established under this effective anti-estuarine circulation during the IIA-B biozone. Life resources (nutrients and oxygen) were generally poor (especially in pelagic realm) but their stability was very high. These conditions gave rise to and then sustained $\mathrm{K}$-selection in foraminiferal community. For that we have the IIA-B assemblage as an excellent example of very high species diversity in both benthic and planktonic foraminifers. Benthic species settled both on the bottom surface and within the sediment although the infaunal varieties have prevailed. Organic matter was entirely used as a constant and predictable resource of food during this time interval. Detritus oxidation or reducing conditions were negligible. The sediments of this biozone were highly bioturbated and well-homogenized. This feature indicates that although temperature controlled stratification the basin bottom was sufficiently oxygenated to maintain and sustained infaunal feeders of macrofauna.

Globorotaliids of the E1 (IIA-B biozone) reveal stratigraphic bipartition: the Globoconella bykovae-Jenkinsella mayeri assemblage precedes the Jenkinsella transsylvanica assemblage. This bipartition is supported by the $\delta^{18} \mathrm{O}$ data (Fig. 6). Globigerina bulloides tests of the G. bykovae-J. mayeri level display a $\delta^{18} \mathrm{O}$ average value: $+0.4 \pm 1.2 \%$ after Durakiewicz et al. (1997) and $-0.7 \pm 0.4 \%$ after Gonera and Bukowski (2012). In the samples of $J$. transsylvanica level there is an $\delta^{18} \mathrm{O}$ value $+0.7 \%$ (single data in Durakiewicz et al., 1997) and has an average value of $+0.4 \pm 0.5 \%$ after Gonera and Bukowski (2012). The $\delta^{18} \mathrm{O}$ difference between these two globorotaliids assemblages is apparent from the Gliwice 17 data (Appendix 1). Globigerina bulloides $\delta^{18} \mathrm{O}$ of the Jenkinsella transsylvanica assemblage is interpreted as a cryptic cooling event, and directly precedes the Mi3 event suggested by Gonera (2001) into the IIC biozone (Fig. 2). This nearly $1 \%$ VPDB increase in $\delta^{18} \mathrm{O}$ indicates that epipelagic temperature could dropped circa $5^{\circ} \mathrm{C}$. In this context it is worth to note that planktonic foraminifera per- 




Fig. 6. Oxygen isotopic differences in the globorotaliid levels (data on Globigerina bulloides measurements after Gonera and Bukowski, 2012)

centage in the $\mathrm{J}$. transsylvanica level is noticeably higher (median $=68 \%$ ) compared to the $G$. bykovae-J. mayeri assemblage (median $=56 \%$ ). This difference had been noted by Alexandrowicz (1963). This author distinguished the IIB assemblage overlaying the assemblage IIA which is taxonomically analogous to the upper lagenide zone of the Vienna Basin. It can now be inferred that the IIB assemblage appearance is the earliest signal of the Mi3 environmental cooling.

This cryptic cooling became a trigger factor to a profound faunal turnover: IIA-B association vanishing and $\| \beta$ appearing (Fig. 2). The J. transsylvanica cryptic cooling, as recorded by ca. $1 \%$ VPDB $\delta^{18} \mathrm{O}$ increase, must have induced an approximate $100 \mathrm{~m}$ eustatic sea level drop. This lowering should have initiated a slope displacement processes leading to mixing of the coeval costal sediments but also the older ones - first of all, poorly consolidated earlier Moravian. Sea level fall also caused the flow efficiency of the current to became sluggish through most likely a cession of some of the shallower corridors and seaways in the Paratethys (E2 in Fig. 2). It was still the anti-estuarine circulation but was less effective than in E1. The surface waters were inflowing and the bottoms were flowing out, although the efficiency of those was diminished compared to $E 1$. In the $I \beta$ biozone (G. bykovae-J. transsylvanica globorotaliid interval) we have $\delta^{18} \mathrm{O}$ value of $-0.48 \%$ (single data in Durakiewicz et al., $1997)$ and $\delta^{18} \mathrm{O}$ average value $+0.02 \pm 0.71 \%$ (Fig. 6 ). It means that in the $I \beta$ biozone pelagic waters were warmer than in $J$. transsylvanica cryptic cooling, however cooler than in $G$. bykovae-J. mayeri interval.

Cooling and shallowing of the basin allowed for a vertical mixing of epipelagic waters. Water salinity was still normal marine but food, oxygen and temperature conditions of the biotope became far off those of the IIA-B biozone. The majority of K-selection species of the IIA-B biozone was removed from the community.

Common signs of redeposition presented in the II $\beta$ biozone sediments include the allochthoneity of foraminifers as well as rhodolith debris. The admixture of these elements into silty marls of II $\beta$ biozone occurs especially frequently near the NE border of the Upper Silesia basin and thus the Kraków-Częstochowa Mesozoic ridge could be a potential source area. From there these and other shallow-water components and mineral particles (glauconite) were spread by slump processes and/or activity of currents.

The pelagic assemblage of the $\| \beta$ biozone is similar to that of the IIA-B biozone but in the first one the intermittent occurrences of Globigerina bulloides-Turborotalita quinqueloba association are present. The planktonic foraminifer percentage of the II $\beta$ biozone varies highly from sample to sample. Generally the group is less frequent than in the IIA-B biozone. Globoconella bykovae had arrived into globorotaliids community of this closing biozone of the CPN 7. In some samples this taxon occurs with $\mathrm{J}$. transsylvanica.

The first biozone of Wielician - IIC - is barren of globorotaliids, and Globigerina bulloides is the only planktonic foraminifer present. The average $\delta^{18} \mathrm{O}$ value of $G$. bulloides tests is $+1.3 \pm 1.1 \%$ (Fig. 6), i.e. significantly higher than in the CPN 7 biozones. The CPN 8 base corresponds to the intense drop of temperature due to global Mi3 event (cf. Gonera, 2001; Gonera et al., 2000, 2003; Baldi, 2006; Peryt and Gedl, 2010; Harzhauser et al., 2011; Gonera and Bukowski, 2012; Key et al., 2013). In the Upper Silesia Basin the percentage of planktonic foraminifers considerably increased; although it was only this one mentioned taxon. Vertical mixing of water has been activated, so a nutrient supply and food resources has been rich but unstable, irregular in appearance (Gonera, 2001). This factor operated as an environmental stress which conditioned the benthic and pelagic foraminifera. As a consequence a community typical to r-selection had been settled. At the bottom only two opportunistic taxa were able to adapt succesfully to these circumstances: Valvulineria and Cibicides. In the pelagic realm the species able to successfully adapt was Globigerina bulloides. Further intensification of these causes which removed the IIA-B biozone community and formed the $\| \beta$ one had led to the establishment of the IIC biozone community.

The IID biozone environment displays a further drop in temperature. In the time-consecutive parts of the Badenian it is the one directly underlying the Wielician evaporites. The average $\delta^{18} \mathrm{O}$ value of $G$. bulloides tests is $+1.9 \pm 0.2 \%$ (Fig. 6 ). It is worth to note that IID Globigerina bulloides of the Wieliczka Mine (vicinity of Kraków) displays an average $\delta^{18} \mathrm{O}$ value is $+2.3 \pm 0.2 \%$ (after Gonera et al., 2012). The IID biozone deposits near Busko show the average $\delta^{18} \mathrm{O}$ value of $2.0 \pm 0.6 \%$ (Peryt, 2013).

Upper Silesia Basin bathymetry was sublittoral during this biozone. Normal marine water salinity and E2 circulation pattern had been sustained. The set of foraminifers and type of sediments indicate oxic conditions. So, these features remain similar to the IIC environment. What was a new environmental factor in the IID zone it were constantly maintained organic-rich conditions caused by a vertical extending of the surface mixed layer in a cooler climate. In the shallow (coastal) areas of the Paratethys this deepening had led to intensify of nutrient supply to photic zone and increase the productivity of pelagic waters. Besides the overall cooling, this was the main factor favouring the Globigerina bulloides acme. These environmental features which where first interpreted through foraminiferal palaeoecological approach (Gonera, 2001) are now supported by $\delta^{13} \mathrm{C}$ data (Gonera and Bukowski, 2012). Globorotaliids arrived to the Upper Silesia Basin during the IID biozone. As can be stated based on the studied material the meaningful number of globorotaliids (17-67\% of planktonic foraminifera) occurs only twice during this biozone. The peak of Globoconella bykovae is noted in three of the analysed boreholes (Pławniowice 1, Sumina 2, Żory 4). The appearance of Globoconella minoritesta has been noted in the Gliwice 19 borehole. As yet any borehole in which these (or any other) globorotaliids are recorded more than one time during IID was found. The interpretation of this is that during IID of the E2 circulation the basin has been invaded at least twice by larger marine inflows of deeper epipelagic waters. One of them was carrying G. bykovae and the second $G$. minoritesta. The inflows were intense enough to carry the most deep epipelagic foraminifers. 


\section{DISCUSSION}

The described globorotaliid intervals are distinctive with regards to taxonomic set. Due to the globorotaliid life-span (deep epipelagic water of marine currents) these foraminifers are capable to be effectively carried to overall connected seas and distributed up to their ecological limits (bathymetry and temperature first of all). Thereby it should be expected that the discovered changes in Middle Miocene Silesia Basin globorotaliids are also recorded in other areas throughout the Paratethys.

The globorotaliid events (and their stratigraphic intervals) offer a reliable supporting method for intra-Paratethyan correlation - independent of the index taxa of the Orbulina suturalis Zone (CPN 7) and the Globigerina druryi-G. decoraperta Zone (CPN 8). At present the straight identification of these globorotaliid levels can to be performed regarding some lower Badenian sections. Such an approach can to be tentatively applied to globorotaliids of the Badenian stratotype section of the Baden-Sooss (Rupp and Hohenegger, 2008). The absence of Jenkinsella mayeri (Paragloborotalia of Rupp and Hohenegger, 2008), the presence of Globoconella bykovae accompanied by Jenkinsella transsylvanica allow to refer their set to the Globoconella bykovae-Jenkinsella transsylvanica level of the Upper Silesia Basin. Two significant percentages of Globoconella bykovae in planktonic foraminifera set have been detected by Kovačová and Hudáčková (2009) in the Slovak part of the Vienna Basin, in the Devinska Nova Ves CPN 8 deposits. As these appearances are positioned at the some stratigraphic interval as in the Upper Silesia basin it may indicate the doubling of Globoconella bykovae interval of the Upper Silesia Basin. In the more marginal, shallow-water deposits the globorotaliid intervals identification is probably also possible but indirect. The good example of this seems to be the lastly recovered two episodes of "mesotrophic or nearly oligotrophic conditions" during the IID biozone in the northern Carpathian Foredeep Basin near Busko (Peryt, 2013). Maybe these events, marked "S3" and "S4" (Peryt, 2013), reflect the same influxes of open marine waters which had carried Globoconella bykovae and Globoconella minoritesta into the Upper Silesia Basin during the IID span. The question of these episodic influxes of open marine waters during the IID biozone may give some assumption to justify the volume of marine water evaporated vs. the volume of Wielician evaporites.

The Paratethys as a set of fringing marine basins of Mediterranean were more sensitive to eustatic sea level fluctuations causing waxing and wanning of marine biotas. This is also the case for globorotaliids, but the basic obstacles to perform a wider correspondence (at least Mediterranean-Paratethys) of the globorotaliid intervals are overcoming taxonomic differences. Thereby a comparison between assemblages of Paratethys and surrounded marine basins is difficult. The only taxonomic consent concerning Paratethys and world-ocean globorotaliids is Jenkinsella mayeri. We can see the morphological similarity of Jenkinsella transsylvanica to Globorotalia challengeri Srinivasan and Kennett, 1981. Globoconella bykovae is morphologically similar to Globorotalia praescitula (Blow, 1959). Nevertheless Subbotina et al. (1960) suggested its similarity to G. foshi (sensu Cushman and Ellisor, 1939). Which world-ocean taxon does G. minoritesta resemble? Taking into account its biconvexity, fourth chamber in the last whorl and highly extended last chamber compared to the penultimate chamber it appears to be very similar to G. miotumida Jenkins 1960.
The recognized temporal changes in Silesian globorotaliids correlate well with large-scale palaeoenvironmental events such as the Middle Miocene climate event Mi3 and the marine circulation mode in the considered area. If carefully examined in the other areas of Paratethys, this globorotaliid issue shall give an image on the spatial distribution of the here described globorotaliid units in the Paratethys. This would be an additional tool to a detailed stratigraphic correlation within the Paratethyan Miocene. Spatial distribution of each of these particular globorotaliid intervals shall provide additional arguments to a more precise reconstruction of the Middle Miocene seaways operating in the Paratethys. It is also a future and promising method to trace the Paratethys-Tethys connecting currents - if the taxonomic justification with at least the Mediterranean Miocene will be performed. These resolutions are not possible until basic comparative analyses will be performed.

\section{CONCLUSIONS}

1. Three globorotaliids stratigraphic intervals have been recognized in the CPN 7 sediments (Orbulina suturalis Zone of the Moravian substage). Two of them are located within the biozone IIA-B: Globoconella bykovae-Jenkinsella mayeri association followed by Jenkinsella transsylvanica. During the final biozone of the CPN 7 (II $\beta$ in Poland) Globoconella bykovae is present accompanied by rare specimens of $J$. transsylvanica. Jenkinsellids do not appear beyond CPN 7/CPN 8 boundary: J. mayeri disappears first followed by J. transsylvanica.

2. Two globorotaliids intervals have been recognized in the CPN 8 sediments (Uvigerina costai zone of the Wielician substage). Globorotaliid absence in IIC biozone is followed by a separate occurrence of Globoconella bykovae and Globoconella minoritesta in the IID biozone.

3. The appearance of Jenkinsella transsylvanica corresponds with the $\delta^{18} \mathrm{O}$ positive excursion circa $1 \%$ VPDB in Globigerina bulloides tests. This is interpreted as cryptic cooling event of Mi3 recorded in Late Moravian (CPN 7). This first step of Middle Miocene climate deterioration caused both the $\mathrm{J}$. mayeri irreversible disappearance and the temporal retreat $G$. bykovae from the Upper Silesia Basin.

4. As much as a $100 \mathrm{~m}$ sea level drop may be generated by cryptic cooling event of the $J$. transsylvanica level. These factors justify the pronounced environmental change and turnover the hitherto foraminiferal community. Firstly, during the cooling episode itself there was a substitution of the upper lagenide assemblage (IIA) by planktonic-rich assemblage IIB. Later - in the II $\beta$ biozone - due to the shoaling slump processes were activated leading to a successive destruction of the Moravian ecosystem. Together with the onset of the next cooling event (IIC biozone) the Moravian ecosystem had been totally demolished. A new ecosystem - this of Wielician - with Globigerina bulloides acme in pelagic waters has been established. The globorotaliid-barren interval IIC preceded two significant influxes of open marine water masses carrying G. bykovae and G. minoritesta - both during the IID biozone, which directly preceded the Wielician evaporitic sedimentation.

5. Globorotaliid life-span makes it possible for a quick and easy dispersion of specimens within marine areas and thus favours the group as datums in stratigraphy. The clearly defined globorotaliid levels of the Skawina Fm. are able to be an effective and precise correlation tool within the Paratethys. Taxonomic 
alignments of Paratethys to apart-Paratethys globorotaliids is required; ongoing opinions on Paratethys-Tethys connection(s) in both stratigraphic and palaeogeographic solutions could be much extended after obtain these additional data.
Acknowledgements. The author would like to thank the Geological Quarterly reviewers K. Holcová, N. Hudáčková and S. Filipescu for comments that helped to improve the manuscript.

\section{REFERENCES}

Alexandrowicz S.W. (1963) Stratigraphy of the Miocene deposits in the Upper Silesian basin (in Polish with English summary). Prace Instytutu Geologicznego, 39.

Alexandrowicz S.W. (1997) Lithostratigraphy of the Miocene deposits in the Gliwice area (Upper Silesia, Poland). Bulletin of the Polish Academy of Sciences, Earth Sciences, 45: 167-179.

Baldi K. (2006) Paleoceanography and climate of the Badenian (Middle Miocene, 16.4-13.0 Ma) in the central Paratethys based on foraminifera and stable isotope $\left(\delta^{18} \mathrm{O}\right.$ and $\left.\delta^{13} \mathrm{C}\right)$ evidence. International Journal of Earth Sciences (Geologische Rundschau), 95: 119-142.

Barwicz-Piskorz W. (1997) Badenian (Miocene) radiolaria from the Gliwice area (Upper Silesia, Poland). Bulletin of the Polish Academy of Sciences, Earth Sciences, 45: 87-95.

Bé A.W.H. (1977) An ecological, zoogeographic and taxonomic review of recent planktonic foraminifera. In: Oceanic Micropaleontology (ed. A.T.S. Ramsay): 1-100. Academic Press, London.

Berggren W.A., Kent D.U., Swisher C. III , Aubry M.P. (1995) A revised Cenozoic geochronology and chronostratigraphy. SEPM Special Publication, 54: 129-212.

Bicchi E., Ferrero E., Gonera M. (2003) Paleoclimatic interpretation based on Middle Miocene planktonic foraminifera: the Silesia Basin (Paratethys) and Monferrato (Tethys) record. Palaeogeography, Palaeoclimatology, Palaeoecology, 196: 265-303.

Blow W.H. (1959) Age, correlation, and biostratigraphy of the Upper Tocuyo (San Lorenzo) and Puzon formations, Eastern Falcon, Venezuela. Bulletins of American Paleontology, 39: 67-251.

Bolli H.M., Saunders J.B. (1982) Globorotalia mayeri and its relationship to Globorotalia siakensis and Globorotalia continuosa. Journal of Foraminiferal Research, 12: 39-50.

Cicha I., Čtyroká J., Jiřiček R., Zapletalová I. (1975) Principal biozones of the Late Tertiary in East Alps and West Carpathians. In: Biozonal division of the Upper Tertiary basins of the Eastern Alps and West Carpathians (ed. I. Cicha): 19-34. IUGS Proccedings of the VI Congress, Bratislava.

Cicha I., Rögl F., Rupp Ch., Čtyroká J. (1998) Oligocene-Miocene foraminifera of the Central Paratethys. Abhandlungen der Senckenbergischen Naturforschenden Gesellschaft, 549: $1-325$.

Cushman J.A., Ellisor A.C. (1939) New species of Foraminifera from the Oligocene and Miocene. Contributions to the Cushman Laboratory of Foraminiferal Research, 15: 1-14.

Durakiewicz T., Gonera M., Peryt T.M. (1997) Oxygen and carbon isotopic changes in the Middle Miocene (Badenian) foraminifera of the Gliwice area (SW Poland). Bulletin of the Polish Academy of Sciences, Earth Sciences, 45: 145-156.

Garlicki A. (1979) Sedimentation of Miocene salts in Poland (in Polish with English summary). Prace Geologiczne, 119.

Gonera M. (2001) Foraminiferida and plaeonevironment of the Badenian formations (Middle Miocene) in Upper Silesia (Poland) (in Polish with English summary). Studia Naturae, 48: 1-211.

Gonera M., Bukowski K. (2012) Isotopic events in the Early/Middle Badenian (Miocene) of the Upper Silesia Basin (Central Paratethys). Geological Quarterly, 56 (3): 561-568.

Gonera M., Peryt T.M., Durakiewicz T. (2000) Biostratigraphical and paleoenvironmental implications of isotopic studies $\left({ }^{18} \mathrm{O}\right.$, ${ }^{13} \mathrm{C}$ ) of middle Miocene (Badenian) foraminifers in the Central Paratethys. Terra Nova, 12: 231-238.
Gonera M., Peryt T.M., Durakiewicz T. (2003) Coiling direction in Globigerina bulloides of Middle Miocene age. Journal of Micropaleontology, 22: 141-146.

Gonera M., Bukowski K., d'Obyrn K., Wiewiorka J. (2012) Foraminifera in slump deposits of the Badenian (Middle Miocene) Green Stratified Salt in Wieliczka, Poland. Geological Quarterly, 56 (4): 869-880.

Harzhauser M., Piller W.E., Müllegger S., Grunert P., Micheels A. (2011) Changing seasonality patterns in Central Europe from Miocene Climate Optimum to Miocene Transition deduced from the Crassostrea isotope archive. Global and Planetary Change, 76: 166-169.

Hemleben Ch., Spindler M., Anderson O. R. (1989) Modern Planktonic Foraminifera. Springer, New York.

laccarino S. (1985) Mediterranean Miocene and Pliocene planktic foraminifera. In: Planktonic Stratigraphy (eds. H. M. Bolli, J. B. Saunders and K. Perch-Nielsen): 263-282. Cambridge University Press.

Jenkins D.G. (1960) Planktonic Foraminifera from the Lakes Entrance oil shaft, Victoria, Australia. Micropaleontology, 6: 345-371.

Kennett J.P., Srinivasan M.S. (1983) Neogene Planktonic Foraminifera. A Phylogenetic Atlas. Hutchinson Ross Publishing Company, Stroudsburg.

Key M.M., Zágoršek K., Patterson W.P. (2013) Paleoenvironmental reconstruction of the Early to Middle Miocene Central Paratethys using stable isotopes from bryozoan skeletons. International Journal of Earth Sciences, 102: 305-318.

Kovačová P., Hudáčková N. (2009) Late Badenian foraminifers from the Vienna Basin (Central Paratethys): stable isotope study and paleoecological implications. Geologica Carpathica, 60: 59-70.

Laskarev V. (1924) Sur les equivalents du Sarmatian superieur en Serbie. In: Recueil de travaux offert a M. Jovan Cvijie per ses amis et collaborateurs (ed. P. Vujevic), Belgrade: 73-85.

Leeuw A. de, Bukowski K., Krijgsman W., Kuiper K.F. (2010) The age of the Badenian Salinity Crisis; impact of Miocene climate variability on the Circum-Mediterranean region. Geology, $\mathbf{3 8}$ 715-718.

Loeblich A.R. Jr., Tappan H. (1988) Foraminiferal genera and their classification. Van Nostrand Reinhold Company, New York.

Łuczkowska E. (1964) The micropaleontological stratigraphy of the Miocene in the region of Tarnobrzeg-Chmielnik (in Polish with English summary). Prace Geologiczne, 20.

Oszczypko N., Krzywiec P., Popadyuk I., Peryt T. (2006) Carpathian Foredeep Basin (Poland and Ukraine): Its sedimentary, structural, and geodynamic evolution. AAPG Memoir, 84: 293-350.

Papp A., Cicha I., Seneš J. (1978a) Gliederung des Badenian, Faunenzonen und Unterstufen. In: Chronostratigraphie und Neostratotypen: Miozän der Zentralen Paratethys (ed. E. Brestenská): 49-52. Bd. VI. M 4 Badenian (Moravien, Wielicien, Kosovien). VEDA SAV, Bratislava.

Papp A., Rögl F., Cicha I., Čtyroká J., Pishvanova L.S. (1978b) Planktonische Foraminiferen im Badenian. In: Chronostratigraphie und Neostratotypen. Miozan der Zentralen Paratethys (ed. E. Brestenská): 268-278. Bd. VI Bratislava, VEDA.

Peryt D. (2013) Foraminiferal record of the Middle Miocene climate transition prior to the Badenian salinity crisis in the Polish 
Carpathians Foredeep basin (Central Paratethys). Geological Quarterly, 57 (1): 141-164.

Peryt D., Gedl P. (2010) Palaeoenvironmental changes preceding the Middle Miocene Badenian salinity crisis in the northern Polish Carpathian Foredeep Basin (Borków Quarry) inferred from foraminifers and dinoflagellate cysts. Geological Quarterly, 54 (4): 487-508.

Popescu G. (1970) Planktonic foraminiferal zonation in the Dej Tuff Complex. Revue Roumaine de Géologie, Géophysique, et Géographie, Série de Géologie, 14: 189-203.

Rögl F. (1998) Palaeogeographic considerations for Mediterranean and Paratethys seaways (Oligocene to Miocene). Annalen des Naturhistorischen Museums in Wien, 99A: 279-310.

Rögl F., Steininger F.F. (1984) Neogene Paratethys, Mediterranean and Indo-Pacific seaways. In: Fossils and Climate (ed. P. Branchley): 171-200. Wiley.

Rupp Ch., Hochenegger J. (2008) Paleoecology of planktonic foraminifera from the Baden-Sooss section (Middle Miocene, Badenian, Vienna Basin, Austria). Geologica Carpathica, 59: 425-445.

Seneš J. (1959) Súčasné znalosti o stratigrafii centrálnej Paratétydy. Geologické Práce, 55.
Seneš J. (1971) Korrelation des Miozans der Zentralen Paratethys (stand 1970). Geologicky Zbornik, 22: 3-9.

Srinivasan M.S., Kennett J.P. (1981) Neogene planktonic foraminiferal biostratigraphy: Equatorial to subantarctic, South Pacific. Marine Micropaleontology, 6: 499-534.

Steininger F.F., Seneš J., Kleeman K., Rögl F., eds. (1985) Neogene of the Mediterranean Tethys and Paratethys. Stratigraphic correlation tables and sediment distribution maps. Univ. Vienna Inst. Paleont.

Subbotina N.N., Pishvanova L.S., Ivanova L.V. (1960) Stratigrafia oligotsenovikh i miotsenovikh otlozheniy Predkarpatya po foraminiferam. Trudy VNIGRI, 153: 5-127.

Szczechura J. (1982) Middle Miocene foraminiferal biochronology and ecology of SE Poland. Acta Palaeontologica Polonica, 27: 3-44.

Witkowski A., Gonera M. (1997) Miocene diatom flora from Central Paratethys (Carpathian Foredeep, Upper Silesia) - preliminary results. Bulletin of the Polish Academy of Sciences, Earth Sciences, 45: 181-190. 